\title{
Fighting for territories: time-lapse analysis of dental pulp and dental follicle stem cells in co-culture reveals specific migratory capabilities
}

\author{
Schiraldi, C ; Stellavato, A ; D’Agostino, A ; Tirino, V ; d'Aquino, R ; Woloszyk, A ; De Rosa, A ; \\ Laino, L ; Papaccio, G ; Mitsiadis, T A
}

\begin{abstract}
Stem cell migration is a critical step during the repair of damaged tissues. In order to achieve appropriate cell-based therapies for tooth and periodontal ligament repair it is necessary first to understand the dynamics of tissue-specific stem cell populations such as dental pulp stem cells (DPSC) and dental follicle stem cells (DFSC). Using time-lapse imaging, we analysed migratory and proliferative capabilities of these two human stem cell lines in vitro. When cultured alone, both DPSC and DFSC exhibited low and irregular migration profiles. In co-cultures, DFSC, but not DPSC, spectacularly increased their migration activity and velocity. DFSC rapidly surrounded the DPSC, thus resembling the in vivo developmental process, where follicle cells encircle both dental epithelium and pulp. Cell morphology was dependent on the culture conditions (mono-culture or co-culture) and changed over time. Regulatory genes involved in dental cell migration and differentiation such as TWIST1, MSX1, RUNX2, SFRP1 and ADAM28, were also evaluated in co-cultures. MSX1 up-regulation indicates that DPSC and DFSC retain their odontogenic potential. However, DPSC lose their capacity to differentiate into odontoblasts in the presence of DFSC, as suggested by RUNX2 up-regulation and TWIST1 down-regulation. In contrast, the unchanged levels of SFRP1 expression suggest that DFSC retain their potential to form periodontal tissues even in the presence of DPSC. These findings demonstrate that stem cells behave differently according to their environment, retain their genetic memory, and compete with each other to acquire the appropriate territory. Understanding the mechanisms involved in stem cell migration may lead to new therapeutic approaches for tooth repair.
\end{abstract}

DOI: https://doi.org/10.22203/eCM.v024a30

Posted at the Zurich Open Repository and Archive, University of Zurich

ZORA URL: https://doi.org/10.5167/uzh-68947

Journal Article

Published Version

Originally published at:

Schiraldi, C; Stellavato, A; D'Agostino, A; Tirino, V; d'Aquino, R; Woloszyk, A; De Rosa, A; Laino, L; Papaccio, G; Mitsiadis, T A (2012). Fighting for territories: time-lapse analysis of dental pulp and dental follicle stem cells in co-culture reveals specific migratory capabilities. European Cells and Materials (ECM), 24:426-440.

DOI: https://doi.org/10.22203/eCM.v024a30 


\section{FIGHTING FOR TERRITORIES: TIME-LAPSE ANALYSIS OF DENTAL PULP AND DENTAL FOLLICLE STEM CELLS IN CO-CULTURE REVEALS SPECIFIC MIGRATORY CAPABILITIES}

Chiara Schiraldi ${ }^{1}$, Antonietta Stellavato ${ }^{1}$, Antonella D’Agostino ${ }^{1}$, Virginia Tirino ${ }^{2}$, Riccardo d'Aquino ${ }^{2}$, Anna Woloszyk ${ }^{4}$, Alfredo De Rosa ${ }^{3}$, Luigi Laino ${ }^{3}$, Gianpaolo Papaccio ${ }^{2 *}$ and Thimios A. Mitsiadis ${ }^{4^{*}}$

${ }^{1}$ Department of Experimental Medicine, Section of Biotechnology, Second University of Naples, Italy ${ }^{2}$ Department of Experimental Medicine, Section of Medical Histology and Embryology, TERM laboratory, Second University of Naples, Italy

${ }^{3}$ Department of Dentistry, Second University of Naples, Italy

${ }^{4}$ Institute of Oral Biology, ZZM, Faculty of Medicine, University of Zurich, Switzerland "Equal senior authors

\begin{abstract}
Stem cell migration is a critical step during the repair of damaged tissues. In order to achieve appropriate cellbased therapies for tooth and periodontal ligament repair it is necessary first to understand the dynamics of tissuespecific stem cell populations such as dental pulp stem cells (DPSC) and dental follicle stem cells (DFSC). Using timelapse imaging, we analysed migratory and proliferative capabilities of these two human stem cell lines in vitro. When cultured alone, both DPSC and DFSC exhibited low and irregular migration profiles. In co-cultures, DFSC, but not DPSC, spectacularly increased their migration activity and velocity. DFSC rapidly surrounded the DPSC, thus resembling the in vivo developmental process, where follicle cells encircle both dental epithelium and pulp. Cell morphology was dependent on the culture conditions (mono-culture or co-culture) and changed over time. Regulatory genes involved in dental cell migration and differentiation such as TWIST1, MSX1, RUNX2, SFRP1 and $A D A M 28$, were also evaluated in co-cultures. $M S X 1$ up-regulation indicates that DPSC and DFSC retain their odontogenic potential. However, DPSC lose their capacity to differentiate into odontoblasts in the presence of DFSC, as suggested by RUNX2 up-regulation and TWISTI downregulation. In contrast, the unchanged levels of SFRPI expression suggest that DFSC retain their potential to form periodontal tissues even in the presence of DPSC. These findings demonstrate that stem cells behave differently according to their environment, retain their genetic memory, and compete with each other to acquire the appropriate territory. Understanding the mechanisms involved in stem cell migration may lead to new therapeutic approaches for tooth repair.
\end{abstract}

Keywords: Tooth; odontoblast; dental follicle; periodontal ligament; dental pulp; dental stem cells; tooth repair; regeneration.

*Addresses for correspondence:

Prof. Thimios A. Mitsiadis,

University of Zurich, Faculty of Medicine, Institute of Oral Biology, ZZM,

Plattenstrasse 11, 8032 Zurich, Switzerland.

Telephone Number: +41 446343390

FAX Number: +41446344310

E-mail: thimios.mitsiadis@zzm.uzh.ch
Prof. Gianpaolo Papaccio, Department of Experimental Medicine, Medical Histology and Embryology,

TERM Laboratory, Second University of Naples, Via L. Armanni 5, 80138 Naples, Italy.

Telephone Number: +390815666014

FAX Number: +390815666014

Email:gianpaolo.papaccio@unina2.it

\section{Introduction}

Cell migration is a widespread, highly dynamic and complex process that is crucial for the appropriate development of organs and tissues (Aman and Piotrowski, 2010; Binamé et al., 2010). Aberrant cell migration often results in severe morphogenetic defects and/or diseases (Friedl and Gilmour, 2009). Reactivation of cell migration underlies tissue repair processes, as well as several pathological conditions, such as metastatic cancers, thus making the study of cell movement clinically relevant.

In order to understand better the mechanisms involved in tissue repair and/or regeneration in vivo, in vitro assay systems have been developed that can bring considerable information about motility and directional migration of cells (Okumoto, 2010; Stephens and Allan, 2003; Wang et al., 2008). Cellular dynamics and functions (e.g. cell migration, proliferation, apoptosis) can be visualised and quantitatively analysed through computational live image processing (Huth et al., 2011; Wang et al., 2008), thus allowing us to obtain biochemical and biophysical information about different cell populations at precise temporo-spatial windows (Aman and Piotrowski, 2010).

Tooth development results from sequential and reciprocal interactions between the oral epithelium and the cranial neural crest-derived mesenchyme (Bluteau et al., 2008; Mitsiadis and Graf, 2009; Mitsiadis and Luder, 2011; Thesleff et al., 1989; Thesleff et al., 1991; Thesleff et al., 1995). Epithelial cells give rise to the enamel producing ameloblasts, while mesenchymal cells are involved in the formation of the dental pulp and dental follicle. Odontoblasts originated by the dental pulp produce the dentin matrix, whereas dental follicle cells contribute to the formation of cementum, periodontal ligament, and alveolar bone (Diep et al., 2009). Periodontal ligament occupies the space between the tooth root and the alveolar bone and serves for tooth anchorage to the bone and masticatory 
force distribution. Although it has been shown that dental follicle cells express a plethora of regulatory molecules (Liu and Wise, 2007; Morsczeck and Schmalz, 2010), the mechanisms controlling their in vivo behaviour (e.g., cell proliferation, migration, and differentiation) remains elusive. Dental follicle cells are in close contact with cells of the dental papilla and root dentin during odontogenesis (Mitsiadis and Luder, 2011; Thesleff et al., 1989), and it has been demonstrated that these interactions constitute an important step for dental follicle differentiation (Bai et al., 2010). Signalling molecules, derived from the dental papilla and root dentin, could be responsible for the proliferation and differentiation of dental follicle cells in vivo (Bai et al., 2010; Mitsiadis and Rahiotis, 2004).

During tooth repair after injury or carious lesion, numerous genes that are expressed throughout embryonic tooth development are reactivated. For example, nestin and Notch molecules are re-expressed in the dental pulp during the reparative processes (Mitsiadis and Rahiotis, 2004). Tooth repair also involves activation of various dental stem cell populations (Mitsiadis et al., 2011). During tissue repair and/or regeneration, stem cells self-replicate, generate daughter cells and finally re-populate the damaged tissue (Laird et al., 2008; Smith, 2001; Smith, 2005). This process requires the oriented or directed movement of stem cells toward this particular anatomic destination (Laird et al., 2008). In human teeth, stem cell populations have been isolated and characterised from dental pulp and dental follicle (Gronthos et al., 2000; Handa et al., 2002; Laino et al., 2005; Miura et al., 2003; Papaccio et al., 2006; Takeda et al., 2008). Dental pulp stem cells (DPSC) and dental follicle stem cells (DFSC) were sorted by FACS using cell-surface markers such as CD117, CD34 and flk-1 for DPSC (d'Aquino et al., 2007; Graziano et al., 2008; Tirino et al., 2011) and SSEA4, OCT-4, TRA1-80 and TRA1-81 for DFSC (d'Aquino et al., 2011). These stem cell populations reside in various niches within the dental pulp and follicle (Lovschall et al., 2007; Mitsiadis et al., 2011). DPSC are very flexible and can differentiate into chondrocytes, adipocytes, neurons, muscles, odontoblasts and bone cells. In vivo, DPSC can form a vascularised pulp-like tissue that is surrounded by odontoblast-like cells (Nakashima and Iohara, 2011). The first clinical trial was successfully performed a few years ago, where DPSC from patients were capable to fully repair their own alveolar bone defects (d'Aquino et al., 2009). Similarly to the DPSC, DFSC exhibit a great differentiation potential (e.g. adipocytes, myoblasts, neurons, glial cells, cementoblasts, periodontal ligament fibroblasts), with the exception of bone formation (d'Aquino et al., 2011; Morsczeck et al., 2005; Yao et al., 2008). Indeed, DFSC are not capable of differentiating into osteoblasts unless a specific culture medium is used (Bai et al., 2010; d'Aquino et al., 2011; Yagyuu et al., 2010; Wu et al., 2008). Taken together these findings indicate that DPSC and DFSC may have different functions when used for tissue repair in vivo. Thus, it is desirable to understand their behaviour in vitro better, before any future clinical application.

In this study we applied time-lapse cell imaging, in an attempt to understand complex biological phenomena related to dental injury and repair/regeneration. We have found that DPSC and DFSC in co-culture behave differently from in mono-culture and compete with each other to increase their vital territory. The fact that DFSC rapidly migrate and occupy most of the culture space by surrounding and restraining the DPSC suggests new criteria for the clinical use of the various stem cell populations during tooth repair.

\section{Materials and Methods}

Subjects, stem cell extraction, digestion, and culture Dental pulps were extracted from intact teeth of 21 to 45 year-old healthy individuals. Dental follicles were collected from wisdom tooth germs with not yet formed roots from 18 to 40 year-old healthy individuals. Dental pulps as well as dental follicles were incubated in a digestive solution composed of $3 \mathrm{mg} / \mathrm{mL}$ type I collagenase and $4 \mathrm{mg} / \mathrm{mL}$ dispase in phosphate buffered saline (PBS) for $1 \mathrm{~h}$ at $37^{\circ} \mathrm{C}$. After enzymatic digestion, the solution was filtered through $70 \mu \mathrm{m}$ Falcon strainers (Becton \& Dickinson, Milan, Italy) and then cells were immersed in DMEM culture medium supplemented with $10 \%$ foetal bovine serum (FBS) (Lonza, Milan, Italy), 100 mM 2P-ascorbic acid, $2 \mathrm{mM}$ L-glutamine, $100 \mathrm{U} / \mathrm{mL}$ penicillin, $100 \mu \mathrm{g} / \mathrm{mL}$ streptomycin (Invitrogen, San Giuliano Milanese, Milan, Italy) and cultured in $75 \mathrm{~cm}^{2}$ flasks with filtered valves (Papaccio et al., 2006). FGF2 (20 ng/mL) was added to the medium for the culture of the dental follicles. Cells were cultured at $37^{\circ} \mathrm{C}$ in a $5 \% \mathrm{CO}_{2}$ incubator. The culture medium was renewed twice per week. Upon confluence, cells were used either for cell sorting or for time-lapse experiments (generally, at the first passage). Digested tissues were permitted to achieve near confluence (90\% of flask surface), which corresponds to $4 \times 10^{5}$ cells $/ 25 \mathrm{~cm}^{2}$ for both cell populations. However, the average doubling time for DPSC is about $3 \mathrm{~d}$ while for DFSC it is $1 \mathrm{~d}$ (for details see Tirino et al., 2011).

\section{Colony efficiency assays and proliferation potential}

To evaluate colony efficiency and proliferation potential, single cells obtained by limiting dilutions were plated. After three weeks of culture, cells were stained with $0.1 \%$ $(\mathrm{w} / \mathrm{v})$ toluidine blue in $1 \%$ paraformaldehyde (PFA) and the number of clones ( $>50$ cells) was counted.

\section{Fluorescence-activated cell sorting (FACS)}

For the collection of DPSC, approximately $1 \times 10^{6}$ dental pulp cells per sample were detached from the flasks, washed and incubated with the CD117 and CD34 antibodies for $30 \mathrm{~min}$ at $4{ }^{\circ} \mathrm{C}$. After incubation, CD34 and CD117 co-expressing cells were sorted using a FACS Aria II BD (BD Biosciences, Milan, Italy). The purity of these sorted cell populations was $90 \%$. The $\mathrm{CD} 34^{+} / \mathrm{CD} 117^{+}$cells were cultured in DMEM supplemented with $10 \%$ FBS and then used for the time-lapse experiments.

For the collection of DFSC, nearly $1 \times 10^{6}$ follicle cells per sample were detached from the flask using $0.02 \%$ EDTA in PBS, pelleted (10 min at 1,000 rpm), washed in $0.1 \%$ bovine serum albumin (BSA) in PBS at $4{ }^{\circ} \mathrm{C}$, and then incubated with the SSEA4 antibody for $30 \mathrm{~min}$ at $4{ }^{\circ} \mathrm{C}$. 


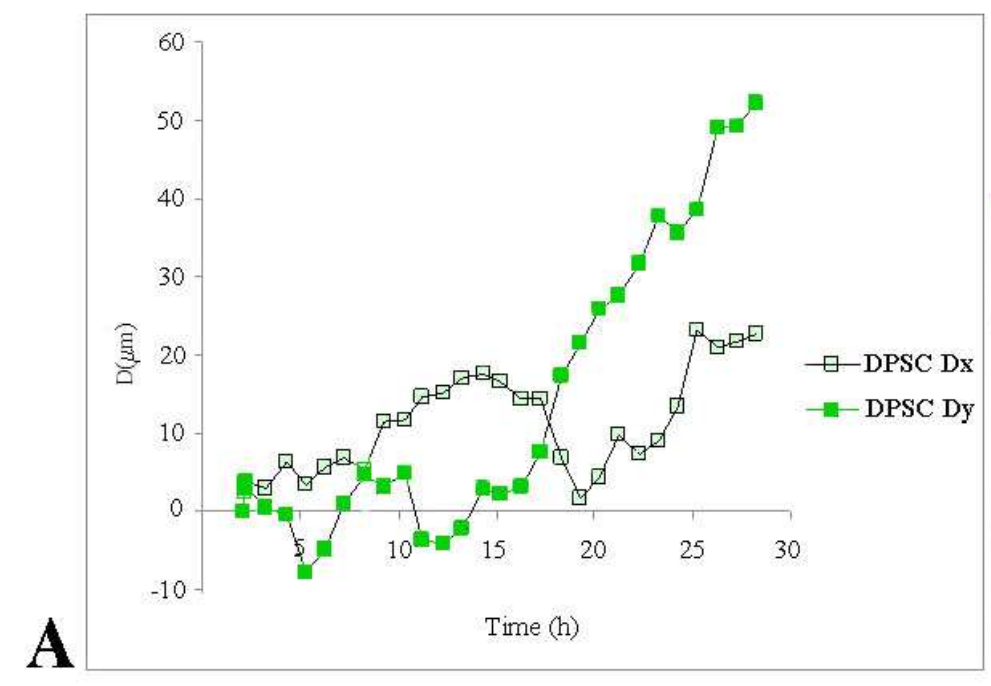

\section{DPSC}
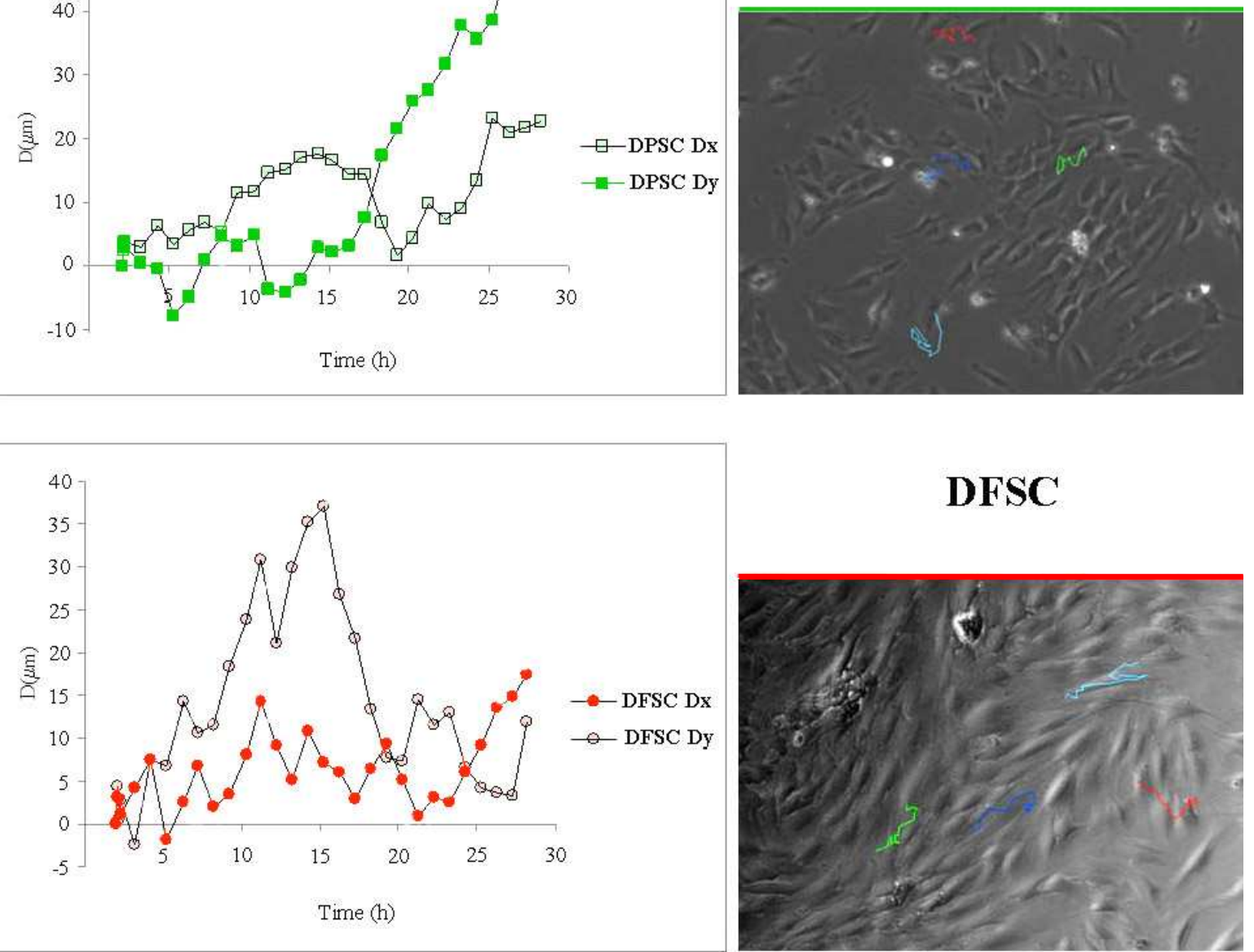

\section{DFSC}

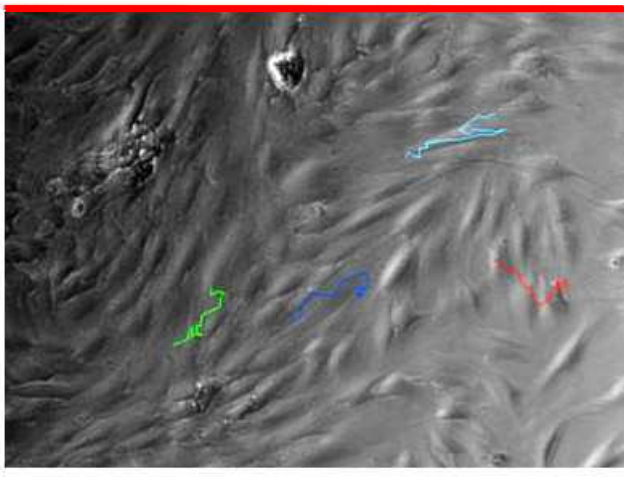

Fig. 1. Cell movement and orientation of DPSC and DFSC cultured alone. (A) When cultured alone, DPSC exhibit a random and restricted motility through the $\mathrm{x}$ or $\mathrm{y}$ axes. Coloured lines (right image) are representative of extracted cell tracks for DPSC in overall time $(30 \mathrm{~h})$. (B) When cultured alone, DFSC show circular movements. Coloured lines (right image) represent extracted cell tracks for DFSC in overall time $(30 \mathrm{~h})$.

After washing, the cells were analysed by flow cytometry and sorted by FACS. The purity of the sorted SSEA4 $4^{+}$ population was $90 \%$. SSEA4 $4^{+}$cells were cultured in DMEM at $10 \%$ FBS and used for time-lapse experiments.

\section{Dye staining}

Lipophilic cell tracking dyes such as PKH26 and PKH67 (Sigma Aldrich, Milan, Italy), use membrane-labelling technology to stabilise the incorporation of a fluorescent dye into the lipid regions of the cell membrane. Lipophilic cell labelling is simple to use and allows the follow up of the tagged cells in vitro and/or in vivo. Therefore, it constitutes a powerful tool for studying the kinetics and behaviour of various cell populations in a heterogeneous environment. DPSC and DFSC were stained with the PKH26 and PKH67 dyes, respectively, at a final concentration of $2 \times 10^{-6} \mathrm{M}$ and $3 \times 10^{5}$ cells $/ \mathrm{mL}$ according to the manufacturer's instructions. Diluent $\mathrm{C}$ is the labelling vehicle provided with the kit, an isosmotic aqueous solution designed to maintain cell viability and maximise dye solubility and staining efficiency (Lee-MacAry et al., 2001).

\section{Time-lapse co-culture experiments}

DPSC were cultured together with DFSC in a standard 24well culture plate with $\mu$-dish ( $35 \mathrm{~mm}$, high) culture-insert (Ibidi, Integrated BioDiagnostics, Munich, Germany). In order to identify the behaviour of these two specific dental stem cell populations in this co-culture system, a series of cell mixtures with different ratio of DPSC/ DFSC (i.e. $1.7 \times 10^{2}$ cells $/ \mathrm{mm}^{2} / 1.7 \times 10^{3}$ cells $/ \mathrm{mm}^{2}\{1: 10\}$, $1.7 \times 10^{3}$ cells $/ \mathrm{mm}^{2} / 1.7 \times 10^{2}$ cells $/ \mathrm{mm}^{2}\{10: 1\}, 2.8 \times 10^{2}$ cells $/ \mathrm{mm}^{2} / 2.8 \times 10^{2}$ cells $/ \mathrm{mm}^{2}\{1: 1\}$ ) were prepared (Fig. 1). Briefly, adherent cells were removed from flasks after $24 \mathrm{~h}$ of culture, using proteolytic enzymes (trypsin/EDTA; Invitrogen, Milan, Italy), immediately re-suspended and either plated as such or labelled prior to seeding. The labelling procedure consists in re-suspending centrifuged cells in $1 \mathrm{~mL}$ of staining solutions (i.e. PKH26 and PKH67) for $5 \mathrm{~min}$, washing in culture medium for fluorescent dye excess removal, and finally seeding and incubating at $37^{\circ} \mathrm{C}$. After $2 \mathrm{~h}$ of incubation, fluorescence microscopy images were taken to analyse the morphology of the cells. The cells were observed for $30 \mathrm{~h}$ on Oko-Full time-lapse 
in bright field and in fluorescence. In particular, the images in bright field were captured every $1 \mathrm{~h}(\Delta \mathrm{t})$, while those in fluorescence were captured every $4 \mathrm{~h}$. This feature allowed us to reduce sample photo-bleaching and cell damage. It is possible to change the acquisition time of the images through a Ludl shutter controlled by the Oko-Vision software. The latter is an optical video-microscopy station, composed of a microscope (Zeiss Axiovert 200), with a $10 \mathrm{x}$ objective in phase contrast, equipped with motorised "stage incubator" for automated sample positioning, a stage incubator where the temperature and the atmosphere were kept at $37{ }^{\circ} \mathrm{C}$ and $5 \% \mathrm{CO}_{2}$, respectively, and controlled humidity. The sequential images were captured by a CCD video camera (ORCA ER, Hamamatsu Photonics, Hamamatsu City, Japan). The monolayer was imaged using phase contrast, while the fluorescently labelled stem cells were imaged using Chroma Filters multi-channel (86013V2), for FITC (excitation BP 450-490 nm, emission LP $515 \mathrm{~nm}$ ) and TRITC (excitation BP $550 \mathrm{~nm}$, emission LP $580 \mathrm{~nm}$ ).

\section{Cell tracking software and analysis}

The time-lapse video microscopy system represents a novel fully automated high-throughput approach for a precise and detailed cell tracking. In time-lapse video microscopy, manual cell tracking remains the most common method for analysing migratory behaviour of cell populations. Cell-Tracker, automatic tracking and analysis software was implemented using oko-vision (version 2009) and consists of a graphical, cross-platform open source application, adjustable to various types of microscopy images and video files. A modular architecture allows for the expansion of image processing and independent tracking. The Graphicator allows plotting of cell coordinates versus time, cell velocity and orientation. Cell-Tracker software allows easy following of cell movement in an interactive way. The cell trajectory is superimposed on the images, for visual validation of the analysis.

Manual tracking was performed with a custom viewing program that enabled storage of $\mathrm{x}$ and $\mathrm{y}$ coordinates by clicking on cells in sequential images with a computer mouse. Manual cell tracking was performed for a total of 4 cells for each field of view (object), for a total of four objects selected in each well. Generally, each condition was repeated at least three times. In addition, each experiment was performed for all cells located within the preselected regions of analysis, during the considered recording time (i.e. $30 \mathrm{~h}-30$ tracks).

The speed and motility of DPSC and DFSC in separate wells were analysed using the above-mentioned software. The speed, area, deformation, trajectory and detailed tracking of the cells were computed and displayed for analysis. The interaction of the two dental stem cell populations was studied in different conditions in the same well. Tabulated data of tracking results were exported into Microsoft Excel for further numerical analysis and evaluated statistically using Student's $t$-test. The conversion factor for measured pixels to microns (1.06 for 10x objective) was determined using a stage micrometer.

Cell-Tracker was plotted as cell coordinates ( $\mathrm{x}$ and $\mathrm{y}$ ) versus time. The cell velocity along $\mathrm{x}$ axis (vector) was calculated by the following equation:

$$
v_{x}=\frac{D x}{t_{f}-t_{0}}
$$

where $D x$ denotes the last cell tracker, $t_{f}$ and $t_{o}$ represent final time and initial time, respectively.

Analyses were performed considering the ratio DPSC/ DFSC $\left(1.7 \times 10^{3}\right.$ cells $/ \mathrm{mm}^{2} / 1.7 \times 10^{2}$ cells $/ \mathrm{mm}^{2}$ and $1.7 \times 10^{2}$ cells $/ \mathrm{mm}^{2} / 1.7 \times 10^{3}$ cells $\left./ \mathrm{mm}^{2}\right)$ per well and the major cell number $\left(1.7 \times 10^{3}\right.$ cells $\left./ \mathrm{mm}^{2}\right)$. Data represent the mean \pm $\mathrm{SD}$ of three independent experiments.

\section{Isolation of total RNA and quantitative real-time (qRT)-PCR}

Total RNA was extracted by using $1 \mathrm{~mL}$ of TRIzol ${ }^{\circledR}$ (Invitrogen, Milan, Italy), according to the manufacturer's instructions. The precipitate was then re-suspended in nuclease-free water. The concentration of the extracted RNA was determined using a Nanodrop spectrophotometer (Celbio, Milan, Italy), and qualitative analysis of the RNA was accomplished by $1 \%$ agarose-gel (w/v) electrophoresis. For cDNA synthesis, performed with the Reverse Transcription System Kit (Promega, Milan, Italy), $1 \mu \mathrm{g}$ of DNase-digested total RNA was used (DNA-free kit; Ambion-Applied Biosystems, Monza, Italy). Quantitative RT-PCR was obtained by using the $\mathrm{iQ}^{\mathrm{TM}} \mathrm{SYBR}^{\circledR}$ Green Supermix (Bio-Rad Laboratories, Milan, Italy) to analyse the expression of TWIST1, MSX1, RUNX2, ADAM28 and $S F R P 1$. BLAST query permitted the specificity analysis of

Table 1. Oligonucleotide primers for real time PCR.

\begin{tabular}{|l|l|l|l|}
\hline Primers & Sequence & Gene Function & $\mathbf{T}^{\circ} \mathbf{C}$ Annealing \\
\hline TWIST-1 & $\begin{array}{l}\text { Sense GGCACCATCCTCACACCTCTG } \\
\text { Antisense TGGCTGATTGGCACGACCTC }\end{array}$ & $\begin{array}{l}\text { Cell lineage determination, } \\
\text { cell differentiation }\end{array}$ & $57^{\circ} \mathrm{C}$ \\
\hline MSX-1 & $\begin{array}{l}\text { Sense ACTGAGACGCAGGTGAAGATATGG } \\
\text { Antisense CCGCCGAGAGGGAAGGAGAG }\end{array}$ & $\begin{array}{l}\text { Craniofacial development, } \\
\text { odontogenesis }\end{array}$ & $55^{\circ} \mathrm{C}$ \\
\hline RUNX-2 & $\begin{array}{l}\text { Sense ACCAGCAGCACTCCATATCTCTAC } \\
\text { Antisense CTTCCATCAGCGTCAACACCATC }\end{array}$ & $\begin{array}{l}\text { Osteoblastic differentiation, } \\
\text { skeletal morphogenesis }\end{array}$ & $55^{\circ} \mathrm{C}$ \\
\hline SFRP-1 & $\begin{array}{l}\text { Sense TGTAATCCAGTCGGCTTGTTCTTG } \\
\text { Antisense GGCTGCTGCTCCACATTGC }\end{array}$ & $\begin{array}{l}\text { Regulation in cancer, } \\
\text { dental follicle development }\end{array}$ & $55^{\circ} \mathrm{C}$ \\
\hline ADAM-28 & $\begin{array}{l}\text { Sense TTGTGGTGGTTGCTATGGTAATCC } \\
\text { Antisense GGCTTCATCTGACTCATCTCTTGG }\end{array}$ & $\begin{array}{l}\text { Cell-cell and cell-matrix } \\
\text { interactions. }\end{array}$ & $56^{\circ} \mathrm{C}$ \\
\hline
\end{tabular}



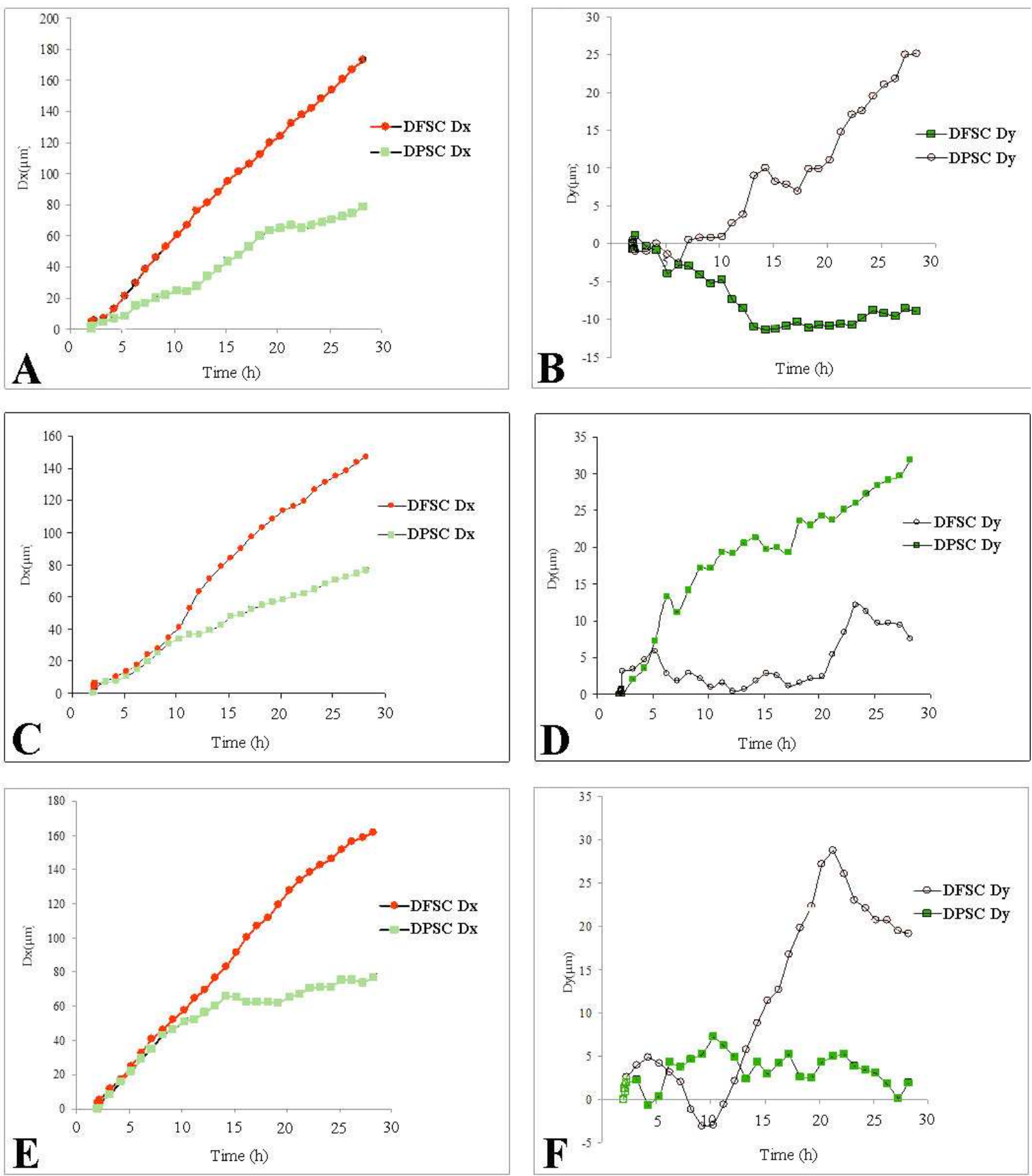

Fig. 2. Cell motility in co-culture of DPSC and DFSC. The graphs show the cell tracker analyses of DPSC and DFSC co-cultured at a ratio 1:1 along $\mathrm{x}(\mathbf{A})$ and $\mathrm{y}$ axis $\mathbf{( B )}$, at a ratio 10:1 along $\mathrm{x}(\mathbf{C})$ and $\mathrm{y}$ axis (D), and at ratio 1:10 along $\mathrm{x}(\mathbf{E})$ and $\mathrm{y}$ axis $(\mathbf{F})$.

each qRT-PCR primer pair, and corresponding sequences were designed by Beacon Designer ${ }^{\mathrm{TM}}$ software. The primer sequences are shown in Table 1. All reactions were carried out in triplicate, and the expression of specific mRNA relative to the control was determined after normalisation with respect to GAPDH gene. The fold-change of test gene mRNA expression was calculated by considering the efficiency of each primer (between 80 and $110 \%$ ), and by using the comparative threshold method $(\Delta \Delta \mathrm{Ct}=$ difference of $\Delta \mathrm{Ct}$ between co-cultured cells and single cell populations used as controls). The results were expressed as normalised fold expression, calculated by the ratio of crossing points of amplification curves of several genes and internal standard, by using the Bio-Rad iQ ${ }^{\mathrm{TM}} 5$ software (Bio-Rad Laboratories Srl).

\section{Results}

Colony efficiency assays and proliferation potential To assess the proliferation and clonogenic potential of DPSC and DFSC, we performed a limiting dilution 

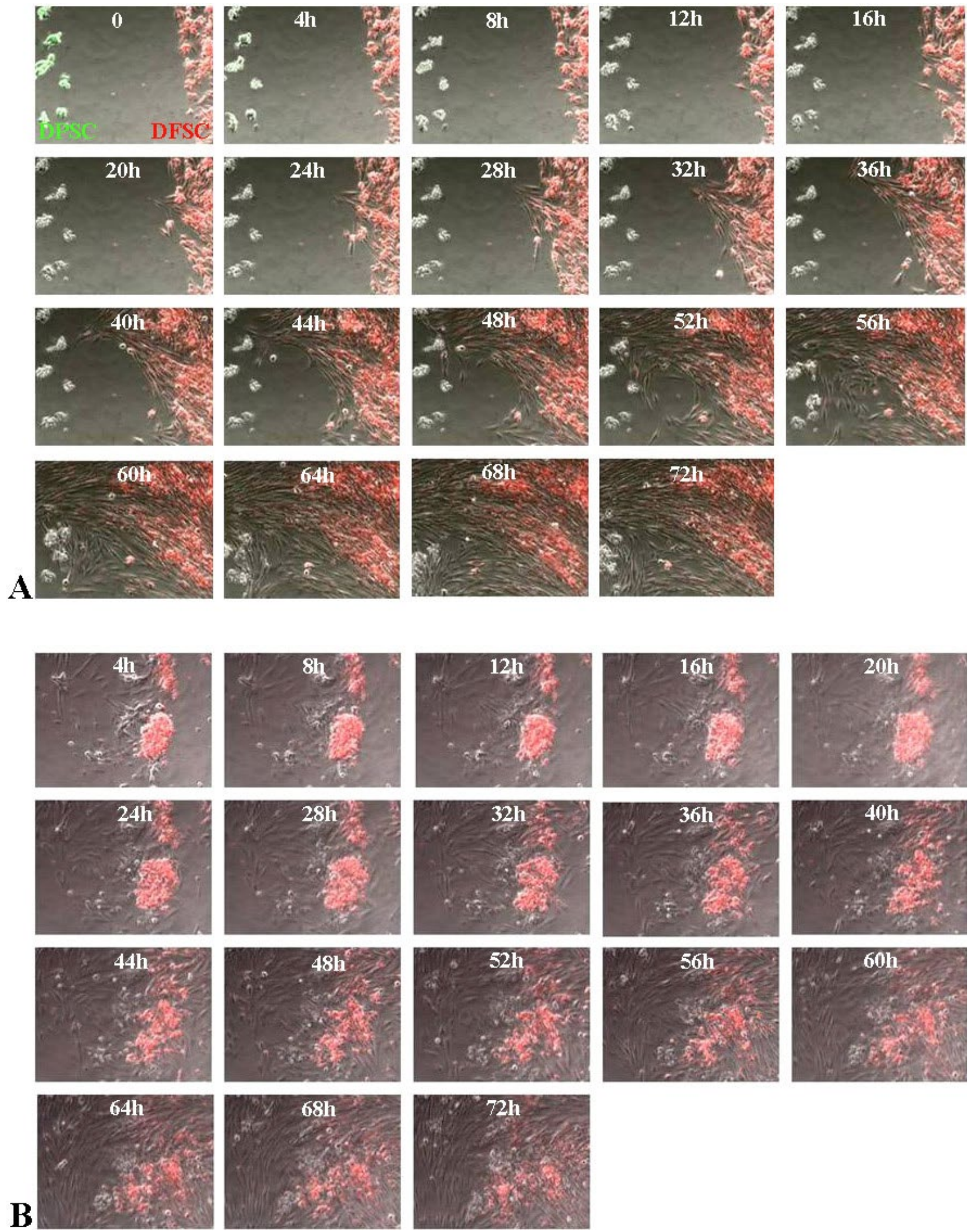

Fig. 3. Time-lapse panel images. (A) DPSC and DFSC in co-culture at a ratio $1.7 \times 10^{2}$ cells $/ \mathrm{mm}^{2} / 1.7 \times 10^{3}$ cells $/ \mathrm{mm}^{2}$ $(1: 10)$. Note that DFSC completely surround DPSC. (B) DPSC and DFSC in co-culture at a ratio $1.7 \times 10^{2}$ cells/ $\mathrm{mm}^{2} / 1.7 \times 10^{2}$ cells $/ \mathrm{mm}^{2}(1: 1)$. Note that DPSC do not move, building up a wall slide by slide. Merge micrographs (bright field, FITC and TRITC) captured at $4 \mathrm{~h}$ intervals. 

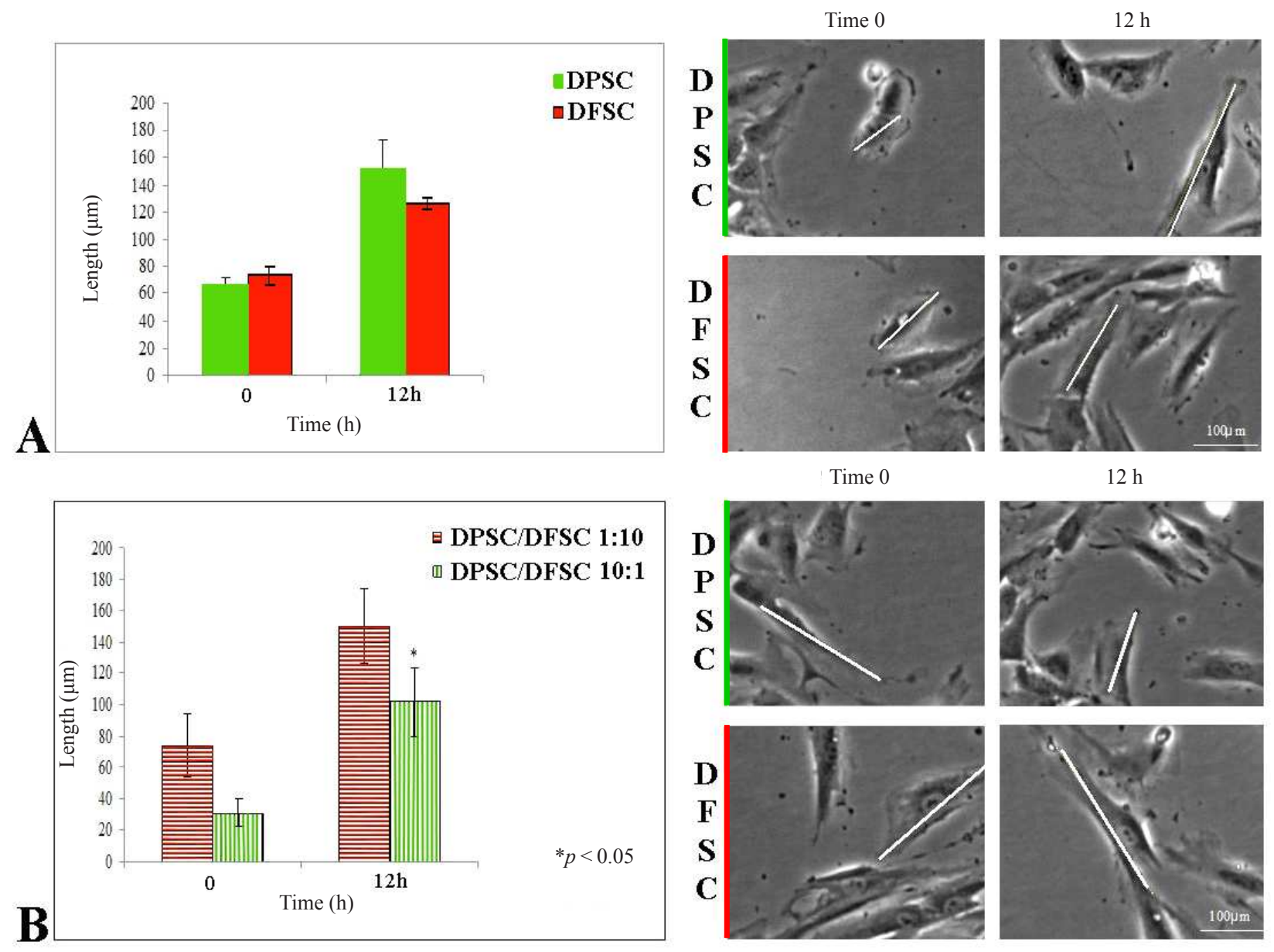

Fig. 4. Cell dimension analysis. (A) Major axis averaged sizes during time of DPSC and DFSC cultured alone, demonstrating that in both populations cells become elongated. (B) Major axis averaged dimensions during time of DPSC and DFSC co-cultured at a ratio 1:10 and 10:1. In both cases DFSC significantly $(p<0.05)$ increase their sizes, whereas DPSC shorten them.

assay. After 3 weeks of culture, $92 \%$ of the wells (442 of 480 ), which were initially plated with one or two DPSC, contained colonies (formed of $>50$ cells), with a doubling time of $\approx 2.6 \mathrm{~d}$. For DFSC, $93 \%$ of the wells (445 of 480 ) contained colonies with a doubling time of $\approx 2.4 \mathrm{~d}$.

\section{Cytometry assay}

To isolate DPSC, dental pulp cells were detected and sorted for co-expression of CD34 and CD117 markers at passage 1 of culture. The positivity of these antigens was $\sim 15 \%$ of the total cell population. To isolate DFSC, dental follicle cells were detected and sorted for SSEA4 expression at passage 1 of culture. The percentage of SSEA4 positivity was $\sim 80 \%$. DPSC and DFSC were sorted and then used for time-lapse and RT-PCR experiments.

\section{Time-lapse observations}

In order to observe the behaviour of DPSC and DFSC in vitro (i.e. cell movement, orientation, morphology and velocity), time-lapse video-microscopy analyses were performed on 6-8 tracks for each image (4 fields of view per well). These two stem cell populations were cultured either alone or together in various cell ratios. As a control, $1 \times 10^{4}$ DPSC or DFSC per well $\left(200 \mathrm{~mm}^{2}\right)$ were used. In cocultures, DPSC and DFSC were seeded separately using a spacer (Culture-Insert). In a first set of experiments, the cell ratio was fixed at 1:1, 1:10 and 10:1 along $\mathrm{x}$ and $\mathrm{y}$ axes, and each stem cell population was stained with a different dye (green colour for DPSC, red colour for DFSC). Analyses of the DPSC and DFSC behaviour were performed on the side of the well containing the greater number of cells $\left(1.7 \times 10^{3}\right.$ cells $\left./ \mathrm{mm}^{2}\right)$.

\section{Cell movement and orientation}

When cultured alone, DPSC and DFSC moved trivially for short distances and often returned in their point of origin (Fig. 1A and B). More precisely, DPSC showed random and small motility through the $\mathrm{x}$ or $\mathrm{y}$ axes (Fig. 1A), while most of the DFSC displayed circular movements within a small perimeter (Fig. 1B). The behaviour of DPSC and DFSC changed significantly in the co-culture experiments, and this was dependent on both the number and ratio of cultured cells.

\section{DPSC/DFSC 1:1 co-culture}

A substantial and interesting change of cell movements was observed when the two stem cell populations were seeded at the same density. In this case, a better linear progression was detected for DFSC movements along both coordinates (x and y axis), as confirmed by curve analyses, although 

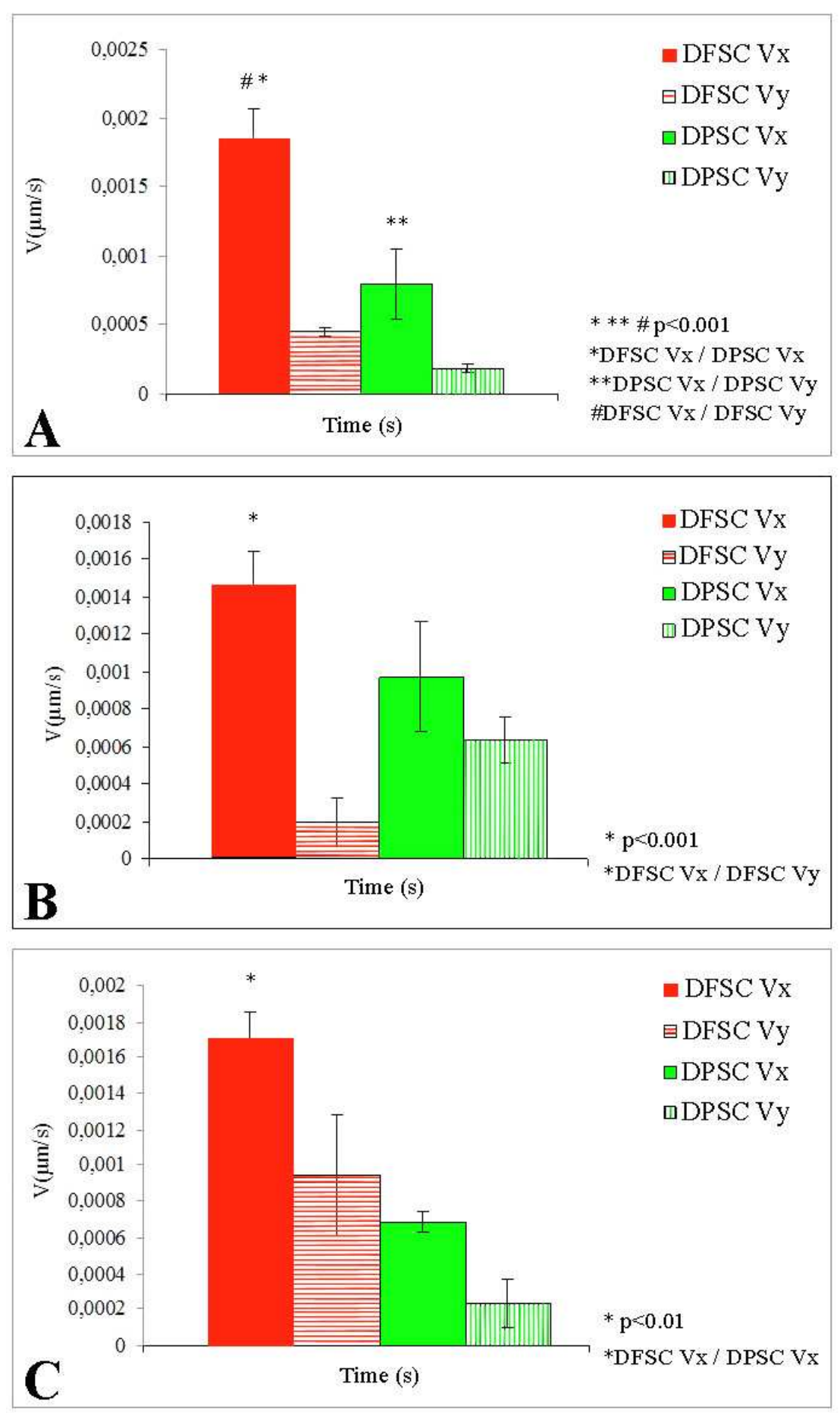

Fig. 5. Cell velocity analysis. DPSC and DFSC in co-culture at a ratio 1:10 (A), 10:1 (B), and 1:1 (C). DFSC result in 2-fold horizontal velocity in comparison with DPSC and even 3-fold along the vertical axis. Data represent the mean \pm SD of three independent experiments. The groups are significantly different according to Student's $t$-test $(p<0.001)$.

DFSC moved oppositely to DPSC along the y axis. The track of DPSC along the $\mathrm{x}$ axis (Dx) was more linear than the track along the y axis (Dy) (Fig. 2A and B).

\section{DPSC/DFSC 10:1 co-culture}

When DPSC and DFSC were co-cultured at a 10:1 ratio, both cell populations exhibited a linear progression along the $\mathrm{x}$ axis (Dx), while cell movements were highly irregular along the $y$ axis. More precisely, DPSC showed only short irregular movements, and remained practically in the same position. In contrast, DFSC covered a long distance, and although their initial movement was irregular it finally became linear and unidirectional (Fig. 2C and D).

\section{DPSC/DFSC 1:10 co-culture}

When DPSC and DFSC were co-cultured at the 1:10 ratio, both cell types showed a linear progression of their movements along the $\mathrm{x}$ axis (Dx), while their movements were irregular along the y axis (Dy). However, DFSC moved more than DPSC along the y axis (Fig. 2E and F). 


\section{Image analyses}

The observation of the panels (Fig. 3) confirmed that there is an interaction between DFSC and DPSC in terms of motility. We observed that DFSC movement was mainly directed along the horizontal axis on the way to surround the DPSC, almost embracing or moving them out, occupying the whole territory in a short period of time (Fig. $3 \mathrm{~A})$. In contrast, the movement of DPSC was comparable to a plug flow along the $\mathrm{x}$ axis, being much slower than that of DFSC. The images clearly showed that DPSC migration was less directional than the DFSC migration (Fig. 3B). At the initial stages of the co-culture (day 1), we have observed "pioneer" DFSC moving towards DPSC (Fig. $3 \mathrm{~A})$. These "pioneer cells" quickly returned to the DFSC territory once they approached or contacted the DPSC. This step may represent a stimulatory signal to the whole DFSC population for starting their migration towards DPSC (see also supplementary movies 1, 2 and 3 on the kinetics of DFSC "red cells" and DPSC "green cells" - on the web page for this paper).

\section{Cell morphology}

Another important point that has been addressed in this study concerns the morphological modifications (i.e. shapes and dimensions) of DPSC and DFSC when cultured either alone or together. We have observed that, when cultured alone, both DPSC and DFSC (which are slightly longer than the DPSC at the starting point) changed their shapes during movement and became considerably flattened and elongated after $12 \mathrm{~h}$ (Fig. 4A). More precisely, cells increased their length by up to 1.7-fold (Table 2). In all co-culture variants, DFSC significantly $(p<0.05)$ increased their size (2-fold higher; Table 2), became elongated and acquired a spindle shape (Fig. 4B). The enveloping attitude of DFSC seemed to induce this restricted elongation of DPSC in co-culture: DPSC decreased in size $(p<0.05)$ and assumed a polygonal shape (Fig. 4B).

\section{Cell velocity}

Concerning cell velocity, in co-cultures of DPSC and DFSC at a ratio $1: 10$, DFSC were twice as fast as DPSC $(p<0.001)$ on the $\mathrm{x}$ axis. On the $\mathrm{y}$ axis, cell movement was slower when compared with the $\mathrm{x}$ axis but also, in this case, DFSC were faster than DPSC (Fig. 5A). In co-cultures of DPSC and DFSC at a ratio 10:1, DPSC $\mathrm{v}_{\mathrm{y}}$ was greater than DFSC $v_{y}$ (Fig. 5B), while at a ratio 1:1, DFSC were significantly faster than DPSC, in both $\mathrm{x}$ and $\mathrm{y}$ axes (Fig. 5C). Specifically, DFSC $v_{x}$ resulted in a 2-fold increase over DPSC horizontal velocity, and even 3-fold along the vertical axis (Fig. 5C). This confirms that DFSC are more active when compared with DPSC.

\section{Real-time PCR observations}

The expression of several genes that are regulators of cell proliferation, migration and differentiation during odontogenesis was evaluated by RT-PCR in our culture system (Table 1). We have used the comparative threshold method $(\Delta \Delta \mathrm{Ct}=$ difference of $\Delta \mathrm{Ct}$ between co-cultured cells and single cell populations used as controls) and the results were expressed as normalised fold expression, calculated by the ratio of crossing points of amplification curves of several genes and internal standard. TWIST1 was markedly up-regulated in DPSC at $24 \mathrm{~h}$, while it was down-regulated at $48 \mathrm{~h}$ (Fig. 6A). In contrast, MSX1 and $R U N X 2$ expression showed a strong down-regulation at $24 \mathrm{~h}$ that changed into a significant up-regulation at $48 \mathrm{~h}$ (Fig. 6A). The expression of SFRP1 was up-regulated at $24 \mathrm{~h}$ and $48 \mathrm{~h}$ of culture (Fig. 6A). ADAM28 expression was drastically up-regulated in DPSC after $48 \mathrm{~h}$ of culture (Fig. 6A).

Analysis of the same profiles of gene expression in co-cultures with prevalent DFSC has shown that the expression of TWIST1 was slightly decreased at $24 \mathrm{~h}$ and $48 \mathrm{~h}$ of culture, whereas expression of MSX1 and ADAM28 were significantly up-regulated after $48 \mathrm{~h}$ of culture (Fig. $6 \mathrm{~B}) . R U N X 2$ expression was initially decreased ( $24 \mathrm{~h})$ and thereafter increased ( $48 \mathrm{~h}) . S F R P 1$ expression was slightly decreased after $48 \mathrm{~h}$ of culture.

\section{Discussion}

Cell-based dental tissue repair or regeneration is an attractive approach that complements traditional restorative and surgical techniques for replacement of injured or pathologically damaged tissues. Such therapeutic approaches often require large numbers of stem cells that after injection migrate towards the injury site following a gradient of directional stimuli. However, a frequent problem of these therapies is the integration of the injected stem cells with the injured or pathological site (Mitsiadis et al., 2012). A deeper appreciation of the mechanisms involved in stem cell behaviour will certainly facilitate cell-based treatments for tissue repair.

In this study, we investigated the in vitro behaviour of two different dental stem cell populations, DPSC and DFSC, using time-lapse imaging. This technique offers an ideal platform for understanding stem cell kinetics in response to injuries and cell-based therapeutic interventions (Aman and Piotrowski, 2010; Wang et al., 2008). The ability of DPSC and DFSC to actively migrate, either randomly or directionally, and fill the empty space during dental tissue repair is an important biological parameter in pathological contexts (Huth et al., 2011). The vast majority of DPSC and DFSC did not show any peculiar or systematic migratory behaviour when cultured separately in vitro. Both DPSC and DFSC exhibit tumbling phases: DPSC showed a limited and random migratory activity, while DFSC followed a circular mode of movement to explore their local environment and often returned to their

Table 2. DPSC and DFSC dimensions when cultured either alone or together.

\begin{tabular}{|c|c|c|}
\hline Major axis length & $\mathbf{T = 0}$ & $\mathbf{T}=\mathbf{1 2} \mathrm{h}$ \\
\hline DPSC & $67.1 \pm 4.1$ & $151.5 \pm 21.7$ \\
\hline DFSC & $73.6 \pm 7.3$ & $126.3 \pm 4.4$ \\
\hline DPSC/DFSC 10:1 & $67.1 \pm 8.7$ & $87.8 \pm 8.2$ \\
\hline DPSC/DFSC 1:10 & $73.7 \pm 20.1$ & $150.0 \pm 23.1$ \\
\hline
\end{tabular}



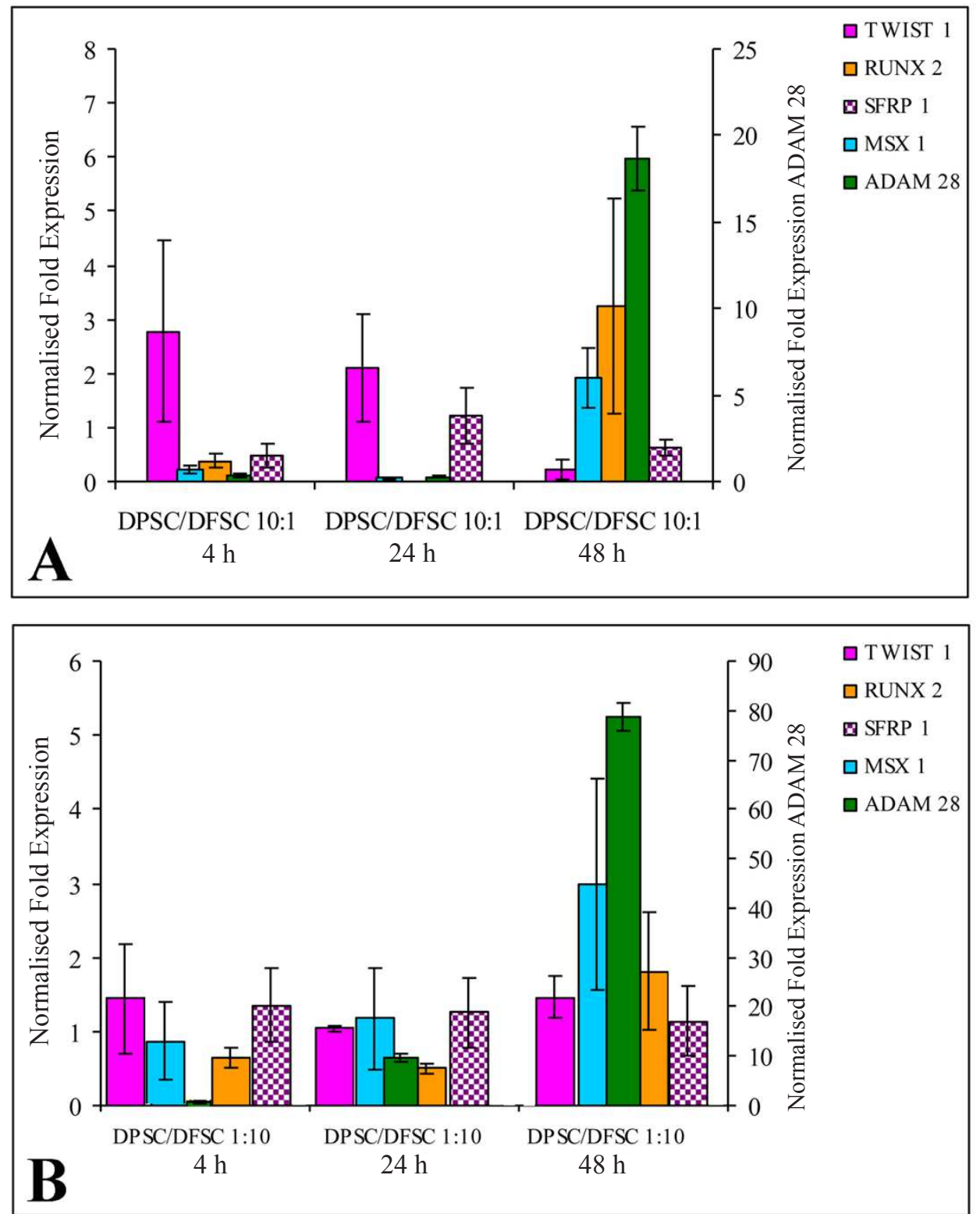

Fig. 6. Gene expression analysis. Images showing normalised fold expression for the genes TWIST 1, MSX 1, RUNX 2, SFRP1 and ADAM 28 in co-cultures of DPSC and DFSC containing (A) a prevalent population of DPSC (DPSC/ DFSC at a ratio 10:1) and (B) a prevalent population of DFSC (DPSC/DFSC at a ratio 1:10).

point of origin. It has been shown that the tumbling phase is cell-autonomous and independent of directional cues such as chemokine signalling (Reichman-Fried et al., 2004). DPSC and DFSC motion was tortuous, probably due to the frequent reversals in directions caused by successive protrusions with opposing orientations. Reduction of direction reversals makes cell movement less tortuous and cells adopt an oriented trajectory towards a chemical or electric signal (Aman and Piotrowski, 2010; Arocena et al., 2010; Zhao et al., 2011a). Indeed, the co-culture of DPSC and DFSC stimulated their migration abilities, particularly when these two stem cell populations were seeded in equal cell numbers. DPSC showed limited proliferation and migration capabilities, and adopted a non-directed random "walk". In contrast, DFSC exhibited quick spreading and directionally migrated towards DPSC. Pre-migratory DFSC started to extend protrusions for guidance and traction in a non-directed fashion. Early DFSC migration serves to populate the empty Petri-dish space, whereas late migration apparently relies on directional cues emanating from DPSC. It has been shown that the direction of late cell migration is established by gradients of repulsive and/or attractant molecules diffusing from the target tissue (Aman and Piotrowski, 2010; Kuriyama and Mayor, 2008). In addition to guidance cues, cell movement requires physical forces that are established through interactions of cells with their environment (Grashoff et al., 2010; Hoffman et al., 2011). In collectively migrating cells, only a few pioneer (or leading) cells perceive guidance cues (Aman and Piotrowski, 2010; Binamé et al., 2010; Friedl and Gilmour, 2009). Indeed, in our co-culture system DFSC started to migrate collectively after getting spatial and directional information from pioneer cells. Migration of pioneer DFSC initially occurred with no interactions with 


\section{in vivo}

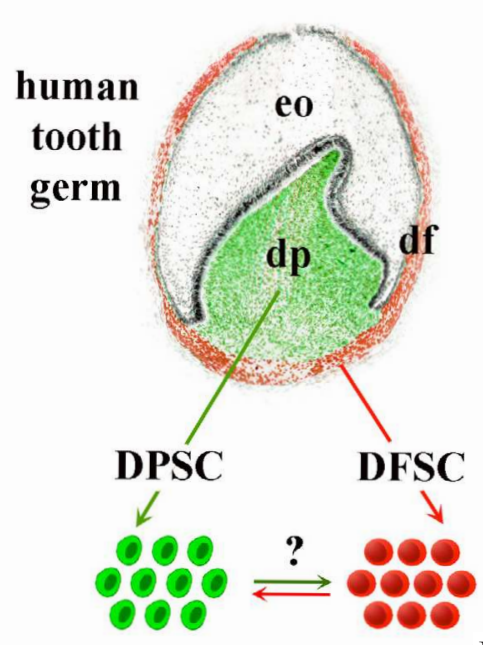

in vitro culture

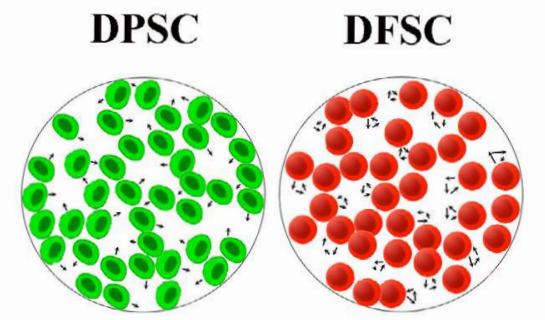

in vitro co-culture

Potential signalling pathway molecules: BMP/TGF $\beta$, Wnt

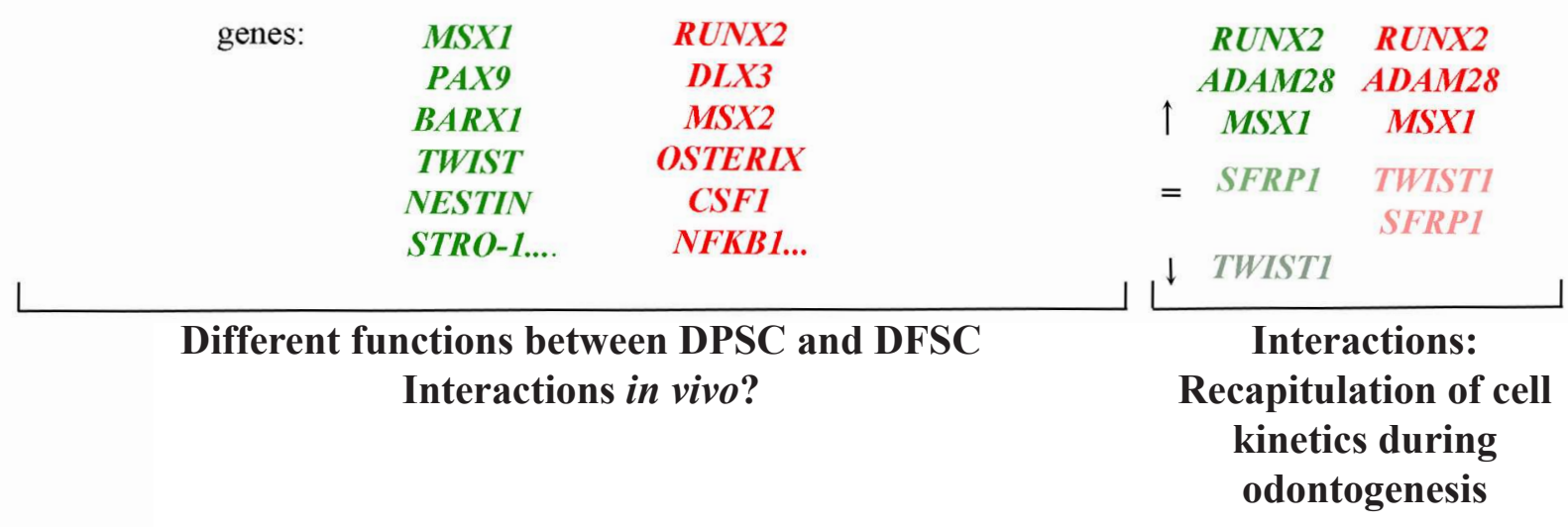

Fig. 7. Schematic representation showing DPSC and DFSC cultured alone or together in vitro. DPSC are isolated from the dental pulp (dp, green colour) and DFSC from the dental follicle (df, red colour), which surrounds both the enamel organ (eo) and dental pulp of the developing tooth. In vivo, the functions of these two stem cell populations are tissue specific, DPSC control repair/regeneration of the dentin-pulp complex, while DFSC operate for the homeostasis and repair of the periodontium. Genes are differentially expressed in dental pulp (e.g. MSX1, PAX9 etc., in green) and dental follicle cells ( $D L X 3, M S X 2$ etc., in red). Signalling pathways such as BMP/TGF $\beta$ and Wnt regulate the expression of these genes. It is not yet known if there are interactions between DPSC and DFSC in vivo after tooth eruption. However, these two stem cell populations interact in co-cultures: DFSC migrate fast (small arrows) towards DPSC (probably due to DPSC-derived attractant signals, green arrow) and finally embrace them. In contrast, DPSC stay on place (possibly because of DFSC-derived repulsive signals, red symbol). This movement recapitulates the kinetics of the dental follicle and dental papilla cells during odontogenesis. Expression of several genes was up-regulated (up looking arrow), unchanged (=), or down-regulated (down looking arrow) in co-cultured DPSC and DFSC.

the trailing DFSC. These pioneer DFSC travel until they reach the DPSC territory, and immediately after contacting DPSC they move back to their point of origin where they transmit the acquired information for an oriented DFSC migration towards DPSC. Shortly afterwards, the trailing DFSC migrate fast as cohorts, occupy most of the empty territory, and finally embrace and restrain the DPSC. This DFSC motion closely resembles that of dental follicle cells during odontogenesis, where they encircle the enamel organ and the dental papilla of the developing tooth germ (Fig. 7). Thus, a step of embryonic tooth development was reiterated in the in vitro co-culture model. The fact that DFSC are isolated from a developing and not yet differentiated tissue that surrounds the not erupted tooth germ might explain the greater migration activity of DFSC compared with DPSC, which are isolated from the mature pulp tissue. Although collectively migrating cells often lose their motility as they reach their target (Aman and Piotrowski, 2010), DFSC at the end of the migratory pathway were still motile.

Tooth damage is the result of different mechanisms of injury combined with the incapacity for intrinsic dental tissue repair. In autologous stem cell-based approaches, patient-related factors, such as the healthy or pathological condition of the dental pulp and periodontal ligament, may influence the quality of the therapeutic preparation 
(Catón et al., 2011). Regeneration of dental pulp does not yet constitute a treatment modality in the clinical field of endodontics. The use of DPSC holds a strong promise in this respect. These cells can differentiate into odontoblasts that will form new dentin, endothelial cells that would support the re-vascularisation and neurons that will reinnervate the regenerated pulp tissue (Catón et al., 2011; Nakashima and Iohara, 2011). If DPSC are injected into the injured area they do not have to migrate fast or over long distances since the pulp space is delimited by the dental mineral structures, thus making DPSC the most appropriate choice for pulp regeneration. Another major challenge in dentistry is the regeneration of the disease-affected periodontal tissues (i.e. tooth root cementum, alveolar bone and periodontal ligament), in a manner that recapitulates embryonic tooth development. Periodontium acts as a suspension for the tooth, adapting to the mechanical and masticatory loads. DFSC are capable of differentiating into all cell types composing the periodontal tissues, they can travel fast and far away from the site of injection, thus ensuring a quick and appropriate tissue recovery.

To improve the use of DPSC for dentin repair and DFSC for periodontal regeneration, it is important to replicate the permissive signals that initiate the differentiation of pulp cells into odontoblasts and of follicle cells into periodontal ligament fibroblasts, respectively (Fig. 7). Such a strategy is likely to restore better the damaged soft and hard dental tissues. WNT proteins are regulators of cell proliferation, migration and differentiation during tooth development and regeneration (Dassule and McMahon, 1998; Sarkar and Sharpe, 2000), and have a great therapeutic potential for hard tissue remodelling and regeneration after injury (Long, 2011; Reya and Clevers, 2005). Recent clinical therapeutic strategies focus on the inhibition of the WNT antagonists such as the SecretedFrizzled Related Protein-1 (SFRP1), which is expressed in dental follicle cells during odontogenesis (Liu and Wise, 2007; Liu et al., 2012; Morsczeck and Schmalz, 2010). SFRP1 expression is regulated by TGF $\beta / B M P$ signalling molecules (Li et al., 2011a) that are involved in dental cell specification and differentiation (Huang et al., 2010; Ko et al., 2007; Mitsiadis and Graf, 2009; Thesleff et al., 1995). For example, aberrant BMP signalling affects odontoblast differentiation and induces ectopic bone formation that replaces normal dentin (Li et al., 2011b). In dental mesenchyme, BMP4 regulates the expression of MSX1 (Vainio et al., 1993), which is a crucial gene for tooth formation since its point mutation in humans causes partial anodontia (Vastardis et al., 1996). The interplay between TGF $\beta / \mathrm{BMP}$ and WNT signalling pathways is needed to ensure dental stem cell specification during tooth repair (Du et al., 2012; Silvério et al., 2012). In our co-culture model, expression of MSX1 was significantly up-regulated in both DFSC and DPSC, indicating that these two stem cell populations have a great capacity to form dental structures. TWIST1 could promote the odontogenic potential of DPSC by antagonising the function of RUNX2 that favours osteoblast differentiation (Li et al., 2011b; Pan et al., 2010; Zhao et al., 2005). However, the coculture of DPSC and DFSC resulted in down-regulation of TWIST1 and significant up-regulation of RUNX2 expression, suggesting that DPSC lose their capacity to differentiate into odontoblasts in the presence of DFSC. SFRP1 expression in DFSC was not altered when DFSC were co-cultured with various ratios of DPSC, indicating that DFSC retain their potential to form periodontal tissues in the presence of DPSC. Recent studies have shown that ADAM28 overexpression has opposite effects on DPSC and DFSC: ADAM28 promotes proliferation of DFSC (Zhao et al., 2010), while it inhibits proliferation and induces differentiation of DPSC (Zhao et al., 2011b). In co-cultures, $A D A M 28$ expression was increased dramatically in both DFSC and DPSC, indicating that the proliferative potential resides within DFSC.

\section{Conclusions}

In conclusion, our observations have highlighted that DFSC and DPSC behave differently in co-culture from when cultured alone and compete with each other in order to replenish the free territory. The fact that DFSC migrate faster than DPSC and dominate them establishes new criteria for the selection and use of specific stem cell populations for the repair and regeneration of particular dental tissues in the clinic. These results, based on dental stem cell lines, could be extrapolated for the controlled regeneration of organs that have important vital functions.

\section{Acknowledgements}

The authors wish to thank the European Science Foundation (ESF) COST Action 1005 NAMABIO, where T.A. Mitsiadis is a management committee member and the representative of Switzerland. This study was supported by the Swiss National Foundation (SNSF) grants 31003A_135633 and 3100A0_118332 (T.A.M.), and by funds from the University of Zurich (T.A.M., A.W.), Second University of Naples (Ateneo 2010) (G.P.), and PON EU Funds "PROMETEO" (01_02834). The authors wish to thank Prof. Mario de Rosa, Director of the CSGA (Centro Servizi Grandi Apparecchiature, Ateneo SUN Napoli, Italy) for providing the time-lapse facilities, Prof. Stefano Guido and Prof. Marino Simeone for helping with the software for image analysis and experimental set-up. We wish to confirm that there are no known conflicts of interest associated with this publication and there has been no significant financial support for this work that could have influenced its outcome.

\section{References}

Aman A, Piotrowski T (2010) Cell migration during morphogenesis. Dev Biol 341: 20-33.

Arocena M, Zhao M, Collinson JM, Song B (2010) A time-lapse and quantitative modelling analysis of neural stem cell motion in the absence of directional cues and in electric fields. J Neurosci Res 88: 3267-3274.

Bai Y, Bai Y, Matsuzaka K, Hashimoto S, Kokubu E, Wang X, Inoue T (2010) Formation of bone-like tissue by 
dental follicle cells co-cultured with dental papilla cells. Cell Tissue Res 342: 221-231.

Binamé F, Pawlak G, Roux P, Hibner U (2010) What makes cells move: requirements and obstacles for spontaneous cell motility. Mol Biosyst 6: 648-661.

Bluteau G, Luder HU, De Bari C, Mitsiadis TA (2008) Stem cells for tooth engineering. Eur Cell Mater 16: 1-9.

Catón J, Bostanci N, Remboutsika E, De Bari C, Mitsiadis TA (2011) Future dentistry: cell therapy meets tooth and periodontal repair and regeneration. J Cell Mol Med 15: 1054-1065.

Dassule HR, McMahon AP (1998) Analysis of epithelial-mesenchymal interactions in the initial morphogenesis of the mammalian tooth. Dev Biol 202: 215-227.

d'Aquino R, Graziano A, Sampaolesi M, Laino G, Pirozzi G, De Rosa A, Papaccio G (2007) Human postnatal dental pulp cells co-differentiate into osteoblasts and endotheliocytes: a pivotal synergy leading to adult bone tissue formation. Cell Death Differ 14: 1162-1171.

d'Aquino R, De Rosa A, Lanza V, Tirino V, Laino L, Graziano A, Desiderio V, Laino G, Papaccio G (2009) Human mandible bone defect repair by the grafting of dental pulp stem/progenitor cells and collagen sponge biocomplexes. Eur Cell Mater 18: 75-83.

d'Aquino R, Tirino V, Desiderio V, Studer M, De Angelis GC, Laino L, De Rosa A, Di Nucci D, Martino S, Paino F, Sampaolesi M, Papaccio G (2011) Human neural crest-derived postnatal cells exhibit remarkable embryonic attributes either in vitro or in vivo. Eur Cell Mater 21: 304316.

Diep L, Matalova E, Mitsiadis TA, Tucker AS (2009) Contribution of the tooth bud mesenchyme to alveolar bone. J Exp Zool B Mol Dev Evol 312B: 510-517.

Du Y, Ling J, Wei X, Ning Y, Xie N, Gu H, Yang F (2012) $\mathrm{Wnt} / \beta$-catenin signaling participates in cementoblast/ osteoblast differentiation of dental follicle cells. Connect Tissue Res 53: 390-397.

Friedl P, Gilmour D (2009) Collective cell migration in morphogenesis, regeneration and cancer. Nat Rev Mol Cell Biol 10: 445-457.

Grashoff C, Hoffman BD, Brenner MD, Zhou R, Parsons M, Yang MT, McLean MA, Sligar SG, Chen CS, Ha T, Schwartz MA (2010) Measuring mechanical tension across vinculin reveals regulation of focal adhesion dynamics. Nature 466: 263-266.

Graziano A, d'Aquino R, Laino G, Proto A, Giuliano MT, Pirozzi G, De Rosa A, Di Napoli D, Papaccio G (2008) Human CD34+ stem cells produce bone nodules in vivo. Cell Prolif 41: 1-11.

Gronthos S, Mankani M, Brahim J, Robey PG, Shi S (2000) Postnatal human dental pulp stem cells (DPSCs) in vitro and in vivo. Proc Natl Acad Sci USA 97: 1362513630.

Handa K, Saito M, Tsunoda A, Yamauchi M, Hattori S, Sato S, Toyoda M, Teranaka T, Narayanan AS (2002) Progenitor cells from dental follicle are able to form cementum matrix in vivo. Connect Tissue Res 43: 406-408.

Hoffman BD, GrashoffC, Schwartz MA (2011) Dynamic molecular processes mediate cellular mechanotransduction. Nature 475: 316-323.
Huang X, Xu X, Bringas P Jr, Hung YP, Chai Y (2010) Smad4-Shh-Nfic signaling cascade-mediated epithelialmesenchymal interaction is crucial in regulating tooth root development. J Bone Miner Res 25: 1167-1178.

Huth J, Buchholz M, Kraus JM, Mølhave K, Gradinaru C, v Wichert G, Gress TM, Neumann H, Kestler HA (2011) TimeLapseAnalyzer: multi-target analysis for live-cell imaging and time-lapse microscopy. Comput Methods Programs Biomed 104: 227-234.

Ko SO, Chung IH, Xu X, Oka S, Zhao H, Cho ES, Deng C, Chai Y (2007) Smad4 is required to regulate the fate of cranial neural crest cells. Dev Biol 312: 435-447.

Kuriyama S, Mayor R (2008) Molecular analysis of neural crest migration. Philos Trans R Soc Lond B Biol Sci 363: 1349-1362.

Laino G, d'Aquino R, Graziano A, Lanza V, Carinci F, Naro F, Pirozzi G, Papaccio G (2005) A new population of human adult dental pulp stem cells: a useful source of living autologous fibrous bone tissue (LAB). J Bone Miner Res 20: 1394-1402.

Laird DJ, von Andrian UH, Wagers AJ (2008) Stem cell trafficking in tissue development, growth, and disease. Cell 132: 612-630.

Lee-MacAry AE, Ross EL, Davies D, Laylor R, Honeychurch J, Glennie MJ, Snary D, Wilkinson RW (2001) Development of a novel flow cytometric cellmediated cytotoxicity assay using the fluorophores PKH-26 and TO-PRO-3 iodide. J Immunol Methods 252: 83-92.

Li J, Huang X, Xu X, Mayo J, Bringas P Jr, Jiang R, Wang S, Chai Y (2011a) SMAD4-mediated WNT signaling controls the fate of cranial neural crest cells during tooth morphogenesis. Development 138: 1977-1989.

Li Y, LuY, MaciejewskaI, GallerK, CavenderA, D'SouzaRN (2011b) TWIST1 promotes odontoblast differentiation. Adv Dent Res 23: 280-284.

Liu D, Wise GE (2007) A DNA microarray analysis of chemokine and receptor genes in the rat dental follicle--role of secreted frizzled-related protein-1 in osteoclastogenesis. Bone 41: 266-272.

Liu D, Yao S, Wise GE (2012) Regulation of SFRP-1 expression in the rat dental follicle. Connect Tissue Res 53: 366-372.

Long F (2011) Building strong bones: molecular regulation of the osteoblast lineage. Nat Rev Mol Cell Biol 13: $27-38$.

Lovschall H, Mitsiadis TA, Poulsen K, Jensen KH, Kjeldsen AL (2007) Coexpression of Notch3 and Rgs5 in the pericyte-vascular smooth muscle cell axis in response to pulp injury. Int J Dev Biol 51: 715-721.

Mitsiadis TA, Graf D (2009) Cell fate determination during tooth development and regeneration. Birth Defects Res C Embryo Today 87: 199-211.

Mitsiadis TA, Luder H (2011) Genetic basis for tooth malformations: from mice to men and back again. Clin Genet 80: 319-329.

Mitsiadis TA, Rahiotis C (2004) Parallels between tooth development and repair: conserved molecular mechanisms following carious and dental injury. J Dent Res 83: 896902. 
Mitsiadis TA, Feki A, Papaccio G, Catón J (2011) Dental pulp stem cells, niches, and notch signaling in tooth injury. Adv Dent Res 23: 275-279.

Mitsiadis TA, Woloszyk A, Jiménez-Rojo L (2012) Nanodentistry: combining nanostructured materials and stem cells for dental tissue regeneration. Nanomedicine 7: $1-11$.

Miura M, Gronthos S, Zhao M, Lu B, Fisher LW, Robey PG, Shi S (2003) SHED: stem cells from human exfoliated deciduous teeth. Proc Natl Acad Sci USA 100: 5807-5812.

Morsczeck C, Schmalz G (2010) Transcriptomes and proteomes of dental follicle cells. J Dent Res 89: 445-456.

Morsczeck C, Götz W, Schierholz J, Zeilhofer F, Kühn U, Möhl C, Sippel C, Hoffmann KH (2005) Isolation of precursor cells (PCs) from human dental follicle of wisdom teeth. Matrix Biol 24: 155-165.

Nakashima M, Iohara K (2011) Regeneration of dental pulp by stem cells. Adv Dent Res 23:313-319.

Okumoto S (2010) Imaging approach for monitoring cellular metabolites and ions using genetically encoded biosensors. Curr Opin Biotechnol 21: 45-54.

Pan K, Sun Q, Zhang J, Ge S, Li S, Zhao Y, Yang P (2010) Multilineage differentiation of dental follicle cells and the roles of RUNX2 over-expression in enhancing osteoblast/cementoblast-related gene expression in dental follicle cells. Cell Prolif 43: 219-228.

Papaccio G, Graziano A, d'Aquino R, Graziano MF, Pirozzi G, Menditti D, De Rosa A, Carinci F, Laino G (2006) Long-term cryopreservation of dental pulp stem cells (SBP-DPSCs) and their differentiated osteoblasts: a cell source for tissue repair. J Cell Physiol 208: 319-325.

Reichman-Fried M, Minina S, Raz E (2004) Autonomous modes of behavior in primordial germ cell migration. Dev Cell 6: 589-596.

Reya T, Clevers H (2005) Wnt signalling in stem cells and cancer. Nature 434: 843-850.

Sarkar L, Sharpe PT (2000) Inhibition of Wnt signaling by exogenous Mfrzb1 protein affects molar tooth size. J Dent Res 79: 920-925.

Silvério KG, Davidson KC, James RG, Adams AM, Foster BL, Nociti FH Jr, Somerman MJ, Moon RT (2012) Wnt/ $\beta$-catenin pathway regulates bone morphogenetic protein (BMP2)-mediated differentiation of dental follicle cells. J Periodontal Res 47: 309-319.

Smith AG (2001) Embryo-derived stem cells: of mice and men. Annu Rev Cell Dev Biol 17: 435-462.

Smith GH (2005) Stem cells and mammary cancer in mice. Stem Cell Rev 1: 215-223.

Stephens DJ, Allan VJ (2003) Light microscopy techniques for live cell imaging. Science 300: 82-86.

Takeda T, Tezuka Y, Horiuchi M, Hosono K, Iida K, Hatakeyama D (2008) Characterization of dental pulp stem cells of human tooth germs. J Dent Res 87: 676-681.

Thesleff I, Vainio S, Jalkanen M (1989) Cell-matrix interactions in tooth development. Int J Dev Biol 33: 91-97.

Thesleff I, Partanen AM, Vainio S (1991) Epithelialmesenchymal interactions in tooth morphogenesis: the roles of extracellular matrix, growth factors, and cell surface receptors. J Craniofac Genet Dev Biol 11: 229-237.

Thesleff I, Vaahtokari A, Partanen AM (1995) Regulation of organogenesis. Common molecular mechanisms regulating the development of teeth and other organs. Int J Dev Biol 39: 35-50.

Tirino V, Paino F, d'Aquino R, Desiderio V, De Rosa A, Papaccio G (2011) Methods for the identification, characterization and banking of human DPSCs: current strategies and perspectives. Stem Cell Rev 7: 608-615.

Vainio S, Karavanova I, Jowett A, Thesleff I (1993) Identification of BMP-4 as a signal mediating secondary induction between epithelial and mesenchymal tissues during early tooth development. Cell 75: 45-58.

Vastardis H, Karimbux N, Guthua SW, Seidman JG, Seidman CE (1996) A human MSX1 homeodomain missense mutation causes selective tooth agenesis. Nat Genet 13: 417-421.

Wang Y, Shyy JY, Chien S (2008) Fluorescence proteins, live-cell imaging, and mechanobiology: seeing is believing. Annu Rev Biomed Eng 10: 1-38.

Wu J, Jin F, Tang L, Yu J, Xu L, Yang Z, Wu G, Duan Y, Jin Y (2008) Dentin non-collagenous proteins (dNCPs) can stimulate dental follicle cells to differentiate into cementoblast lineages. Biol Cell 100: 291-302.

Yagyuu T, Ikeda E, Ohgushi H, Tadokoro M, Hirose M, Maeda M, Inagake K, Kirita T (2010) Hard tissue-forming potential of stem/progenitor cells in human dental follicle and dental papilla. Arch Oral Biol 55: 68-76.

Yao S, Pan F, Prpic V, Wise GE (2008) Differentiation of stem cells in the dental follicle. J Dent Res 87: 767-771.

Zhao Z, Zhao M, Xiao G, Franceschi RT (2005) Gene transfer of the Runx2 transcription factor enhances osteogenic activity of bone marrow stromal cells in vitro and in vivo. Mol Ther 12: 247-253.

Zhao Z, Wang Y, Wang D, Liu H (2010) The regulatory role of a disintegrin and metalloproteinase 28 on the biologic property of human periodontal ligament stem cells. J Periodontol 81: 934-944.

Zhao Z, Watt C, Karystinou A, Roelofs AJ, McCaig CD, Gibson IR, De Bari C (2011a) Directed migration of human bone marrow mesenchymal stem cells in a physiological direct current electric field. Eur Cell Mater 22: 344-358.

Zhao Z, Liu H, Wang D (2011b) ADAM28 manipulates proliferation, differentiation, and apoptosis of human dental pulp stem cells. J Endod 37: 332-339.

\section{Discussion with Reviewers}

Reviewer I: As the authors are experts in the dental field, could they discuss the possibility of using mixed populations of DPSC and DFSC in transplantations targeting tooth repair?

Authors: Dental follicle cells and dental papilla cells are in close contact during odontogenesis. Signalling molecules from the dental papilla could promote proliferation and differentiation of dental follicle cells during development. Indeed, in our co-culture model we have shown that DPSC stimulated the migration abilities of DFSC. In addition, previous results have shown that, in co-culture, DPSC can promote differentiation of DFSC and formation of hard tissues (Bai et al., 2010). We hypothesise that the use of mixed DFSC and DPSC populations for tooth repair may accelerate cytodifferentiation and hard matrix deposition 
events. However, it is of importance to carefully define the appropriate percentage and dosage of DFSC and DPSC according to the targeted dental tissue (dental pulp or periodontal tissues). Taking these parameters into account, repair of the dentin-pulp complex and/or periodontal tissues could occur in a faster than normal way.

In the co-culture, DFSC motion closely resembles that of dental follicle cells during odontogenesis. Dental follicle cells encircle the enamel organ and the dental papilla of the developing tooth germ. DFSC could also be used for the regeneration of a follicle around a tooth germ formed in vitro (recombination of dental epithelium with dental papilla mesenchyme: formation of a brand new tooth). Once the follicle will form around the tooth germ, the explant could be implanted into the alveolar bone in vivo. This technique will probably allow the development and eruption of a new tooth with all appropriate tissues and possible functions.

Reviewer II: DPSC and DFSC seem to be both originated from mesenchymal stem cells because they share similar surface markers and give rise to similar cell types. However, they do have different migration activity in vitro. What mechanisms underly the different migration capacity? How this can be used in regenerative medicine? Authors: Briefly, the difference in the migration activity in the in vitro co-culture system can be explained by the fact that DFSC are isolated from a developing tissue (neural crest-derived mesenchymal tissue that forms the dental sac, which surrounds the epithelial enamel organ and the mesenchymal dental papilla of the developing tooth germ before eruption) and might thus exhibit a greater migration activity than DPSC, which belong to a tissue that is already developed and mature.

In the recent literature there are not many articles concerning this topic. In particular, there is a description of receptors and soluble factors involved in the migration but there is not a substantial difference between the two stem cell populations (DPSC and DFSC). To our knowledge, this is the first study on the co-culture of human DPSC and DFSC, thus allowing the investigation of specific/mediated interactions between these two stem cell populations. In fact, we highlighted that their behaviour differs in single population cultures compared with the co-culture assay, which allows an insight on cell kinetics and gene expression modulation. Several recent papers have reported on the migration of DPSC in the presence of different chemoattractants (EMPs) and/or induced migration of DPSC by selective cytokines (e.g. Howard et al., 2010; Suzuki et al., 2011). However, the migration of DFSC, as well as the migration in a co-culture model, have not been explored in these or other papers. It has been demonstrated that TGF $\beta 1$, an important signalling molecule for tissue regeneration and a marker for functional odontoblasts (Melin et al., 2000), and SPARC, a non-collagenous protein localised in dentin and bone, are able to stimulate DPSC migration (Pavasant et al., 2008). However, these studies report on DPSC migration, but not in DFSC. The role of the various signalling molecules (IGF, EGF, FGF etc) involved in DPSC and DFSC migration is still unknown.

It is well known that in vivo, DPSC and DFSC are localised in specific compartments of the tooth organ and their roles are distinct. The in vitro interaction between DPSC and DFSC could be useful for better understanding the complex in vivo mechanisms involved in repair of specific dental tissues. Few reports hypothesise such interactions between different cell populations of the craniofacial complex. For example, Tancharoen et al. (2005) have studied the influence of neuropeptides released from dental pulp cells in the periodontal tissue and suggested a link between periodontitis and pulp inflammation. The results of the study show that DFSC and DPSC in our in vitro co-culture system recapitulate the in vivo kinetics during odontogenesis, where dental follicle cells surround the dental pulp before the eruption of the tooth. This property of DFSC may be used for the reconstitution of tooth germs in vitro or ex vivo, thus allowing their implantation into the alveolar bone for the replacement of missing teeth (Mitsiadis and Papagerakis, 2011).

\section{Additional References}

Howard C , Murray P and Kenneth NN (2010) Dental pulp stem cell migration. J Endod 36: 1963-1966.

Melin M, Joffre-Romeas A, Farges JC, Couble ML, Magloire H, Bleicher F.(2000) Effects of TGFbetal on dental pulp cells in cultured human tooth slices. J Dent Res 79: 1689-1696.

Mitsiadis and Papagerakis (2011) Regenerated teeth: the future of tooth replacement? Regen Med 6: 135-139.

Pavasant P, Yongchaitrakul T. (2008) Secreted protein acidic, rich in cysteine induces pulp cell migration via alphavbeta3 integrin and extracellular signal-regulated kinase. Oral Dis 14: 335-430.

Suzuki T, Lee CH, Chen M, Zhao W, Fu SY, Qi JJ, Chotkowski G, Eisig SB, Wong A, Mao JJ. (2011) Induced migration of dental pulp stem cells for in vivo pulp regeneration. J Dent Res 90: 1013-1018.

Tancharoen S, Sarker KP, Imamura T, Biswas KK, Matsushita K, Tatsuyama S, Travis J, Potempa J, Torii M, Maruyama I. (2005) Neuropeptide release from dental pulp cells by RgpB via proteinase-activated receptor-2 signaling. J Immunol 174: 5796-5804. 